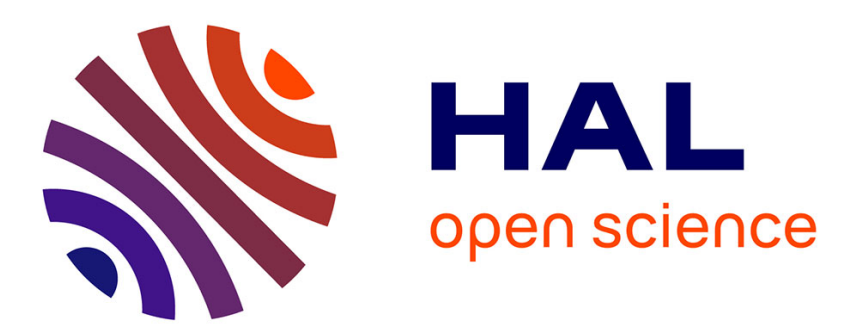

\title{
Process Assessment Issues of the ISO/IEC 29110 emerging standard
}

Vincent Ribaud, Philippe Saliou

\section{To cite this version:}

Vincent Ribaud, Philippe Saliou. Process Assessment Issues of the ISO/IEC 29110 emerging standard. PROFES 2010, Jun 2010, Ireland. pp.28-31. hal-00504446

\section{HAL Id: hal-00504446 \\ https://hal.univ-brest.fr/hal-00504446}

Submitted on 20 Jul 2010

HAL is a multi-disciplinary open access archive for the deposit and dissemination of scientific research documents, whether they are published or not. The documents may come from teaching and research institutions in France or abroad, or from public or private research centers.
L'archive ouverte pluridisciplinaire HAL, est destinée au dépôt et à la diffusion de documents scientifiques de niveau recherche, publiés ou non, émanant des établissements d'enseignement et de recherche français ou étrangers, des laboratoires publics ou privés. 


\section{Process Assessment Issues of the ISO/IEC 29110 emerging standard}

\author{
Vincent Ribaud \\ LISyC, Université de Brest, UEB, France \\ 20 avenue Le Gorgeu, C.S. 93837 \\ 29238 Brest Cedex 3 \\ +33298016971 \\ ribaud@univ-brest.fr
}

\author{
Philippe Saliou \\ LISyC, Université de Brest, UEB, France \\ 20 avenue Le Gorgeu, C.S. 93837 \\ 29238 Brest Cedex 3 \\ +33298016974 \\ Philippe.Saliou@univ-brest.fr
}

\begin{abstract}
The emerging ISO/IEC 29110 standard "Software Engineering Lifecycle Profiles for Very Small Entities (VSE)" is an ISO initiative to provide Very Small Entities (VSE) with a suitable set of profiles for Process Assessment and Process Improvement. The approach is conforming to ISO 15504 2-D model of process capability: a process dimension based on a Process Reference Model (PRM), and a capability dimension with a set of process attributes grouped into capability levels. The ISO/IEC 29110 standard is developing 4 profiles for VSEs developing generic software: Entry, Basic, Intermediate and Advanced. This paper establishes a reduced set of Base Practices profiled from ISO 15504-5 "An exemplar Process Assessment Model (PAM)". It applies recommendations of ISO/IEC 29110 DTR 29110-3 about assessment and questions the use of a separated capability dimension and its usability for a VSE.
\end{abstract}

\section{Categories and Subject Descriptors}

D.2.O [Software Engineering]: General - Standards.

\section{General Terms}

Documentation, Standardization.

\section{Keywords}

ISO/IEC 29110, software engineering processes, process assessment model.

\section{INTRODUCTION}

Very Small Entities (VSE) produce software components stand-alone or integrated in large software systems. A VSE is an entity (enterprise, organization, department or project) having up to 25 people [1]. Most of VSEs cannot afford the resources, nor do they see a net benefit in establishing standardized software life cycle processes [1]. To rectify some difficulties, the ISO/IEC Working Group 24 is developing a set of documents under the emerging ISO/IEC 29110 standard "Lifecycle profiles for Very Small Entities" [1]. The documents are based on subsets of

Permission to make digital or hard copies of all or part of this work for personal or classroom use is granted without fee provided that copies are not made or distributed for profit or commercial advantage and that copies bear this notice and the full citation on the first page. To copy otherwise, or republish, to post on servers or to redistribute to lists, requires prior specific permission and/or a fee.

Post-print submitted to PROFES'10, June, 2010, Limerick, Irlande. Copyright 2010 Universitalia, Roma, Italy. appropriate standards elements, referred to as Profiles [2]. For the VSEs developing generic software, four profiles are being developed: Entry, Basic, Intermediate and Advanced (ISO/IEC FDIS 29110-4-1). The Basic Profile has been submitted to ISO for final balloting (ISO/IEC DTR 29110-5-1-2) and is used as a basis for the work reported in this paper. The Process Assessment Model (PAM) of ISO/IEC 29110 standard is a two-dimensional model of process capability. In the process dimension, the processes are defined and classified into process categories. The capability dimension defines a set of process attributes grouped into capability levels. Process attributes are the measurable characteristics of process capability. Process capability indicators are the means of achieving the capabilities addressed by the considered process attributes. Evidence of process capability indicators supports the judgment of the degree of achievement of the process attribute [3, Part 5, p. 79].

The process dimension of the ISO/IEC standard 15504 [3] provides a complete view of the prescribed work to be done in a software project. Thus, profiling this process dimension through the ISO/IEC 29110 recommendations yields a useful set of Base Practices (an activity that, when consistently performed, contributes to achieving a specific process purpose [3]) for a VSE intending to implement the Basic Profile. This reduced set is presented in section 3 and may be considered as an ISO/IEC 29110 Process Reference Model (PRM). Section 4 addresses the problem of a VSE that wishes to carry an ISO/IEC 29110 assessment against the PRM of section 3. We make the proposal to integrate Level 2 indicators within the PRM to provide the VSE with a unified view of reference and assessment models.

\section{REQUIREMENT and RELATED WORK 2.1 SE Standards for Very Small Entities}

\subsubsection{ISO/IEC 29110 initiative}

ISO started in 2005 a Working Group mandated to develop a set of standards and technical reports suitable to VSEs audience. The profiles are based on subsets of appropriate standards elements, relevant to the VSE, for example, processes and outcomes of ISO/IEC 12207 [4] and products of ISO/IEC 15289 [5]. ISO/IEC DTR 29110-5-1-2 provides Management and Engineering Guide to the ISO/IEC FDIS 29110-4-1 processes.

\subsubsection{Process Assessment}

ISO/IEC DTR 29110-3 is an Assessment Guide applicable to VSE profiles. It is compatible with ISO/IEC 15504-2 and 15504-3. The assessment has two purposes: to evaluate the process capability based on a two-dimensional assessment model 
(issued from the 15504 standard); to determine whether an organization achieves the targeted VSE Profile based on the evaluated capabilities for the processes. A VSE Process Assessment Model (PAM) can be derived by selecting only the assessment indicators in the 15504-5 Exemplar PAM, relevant to corresponding process outcomes defined in ISO/IEC 29110-4-1.

\subsection{Software Process Assessment for VSEs}

A lot of research has been performed on Software Process Assessment (SPA) for small companies based either on 15504 [6, 7, 8] or CMMI [9, 10]. Almost all approaches aims to minimize the assessment time and are reducing the number of assessed processes. As an example, the ADEPT method [10] is selecting six of the seven processes areas associated with CMMI maturity Level 2, and six of the 14 applicable to Level 3. Several approaches are using process-area interviews (or questionnaires) as the central stage to collect evidences of process achievement.

Grünbacher reports on the experiences of an assessment and improvement process in a small software company [9]. The process is based on an initial self-evaluation with the SynQuest self-assessment tool and following structured interviews in the company. The process areas covered in the questionnaire are mainly related to level two and three of the CMM. We agree with the necessity of self-assessment in a VSE but we are going further and try to avoid (almost completely) interviews and coaching.

A Brazilian approach, MARES [6], is a set of guidelines for conducting 15504-conformant process assessments, focused on small companies. MARES first component is a set of process profile patterns, identifying high-priority processes and their respective capability-level goal to contribute to the organization's business goals. MARES second component is a set of heuristics for adapting the patterns to a specific organization. von Wangenheim and al. report that MARES results indicate the 15504 standard's applicability to small Brazilian companies [6]. ISO/IEC 29110 standard uses also profiles but we reached difficulties to implement a 2-D assessment model within VSEs.

\section{Process Dimension}

\subsection{Reference Models}

\subsubsection{Basic Profile Processes}

The ISO/IEC FDIS 29110-4-1 [1] is an International Standard Profile (IS) identified as Basic Profile. This IS applies more specifically to a VSE that is involved in software development of a single application by a single project team with no special risk or situational factors.

The Basic Profile is made of 2 processes: Project Management (PM) and Software Implementation (SI). Processes are described with: name; purpose; objectives; input, output, and internal products; roles involved, activities list and activities description. Each process objective includes a list of the chosen processes for the basic profile from ISO/IEC 12207 and its outcomes related to the objective. We established the coverage of the Basic Profile for the 12207 and 15504 set of processes. This coverage is given in Table 1. Some ISO/IEC 29110 activities shall be mapped to 12207 Activities or 15504 Base Practices (BPs) rather than 12207 processes (in this case, the activity name is in italics). ISO/IEC FDIS 29110-4-1 provides a set of cohesive tasks of each activity. For instance, the starting point of the ISO/IEC 29110 use for requirement is the SI.2 "Software Requirements Analysis" activity. This part establishes also VSE needs and suggested competencies. For instance, it defines the SI.O2 objective "Software requirements are defined, analyzed for correctness and testability, approved by the Customer, baselined and communicated. Changes to them are evaluated for cost, schedule and technical impact previously to be processed [1, Part 4, p. 8]". ISO/IEC DTR 29110-5-2 details, for each activity of the PM and SI processes, the tasks to be performed: role, description of the task, inputs and outputs products. For instance, it defines SI.2.1 to SI.2.7 tasks and their associated output products: Requirements Specification, Verification Results, Change Request, Validation Results, and Software User Documentation.

Table 1. Basic Profile Process Breakdown

\begin{tabular}{|c|c|c|}
\hline Activities & $\begin{array}{c}\text { 12207:2008 related } \\
\text { processes or } \\
\text { activities }\end{array}$ & $\begin{array}{c}\text { 15504:2006 related } \\
\text { processes or Base } \\
\text { Practices }\end{array}$ \\
\hline $\begin{array}{l}\text { PM.1 Project } \\
\text { Planning }\end{array}$ & $\begin{array}{l}\text { 6.3.1 Project } \\
\text { Planning }\end{array}$ & $\begin{array}{l}\text { MAN.3 Project } \\
\text { Management }\end{array}$ \\
\hline $\begin{array}{l}\text { PM.2 Project Plan } \\
\text { Execution }\end{array}$ & - & - \\
\hline $\begin{array}{l}\text { PM.3 Project } \\
\text { Assessment and } \\
\text { Control }\end{array}$ & $\begin{array}{l}\text { 6.3.2 Project } \\
\text { Assessment and } \\
\text { Control }\end{array}$ & MAN.3 \\
\hline $\begin{array}{l}\text { PM.4 Project } \\
\text { Closure }\end{array}$ & $\begin{array}{l}\text { 6.3.2.3.4 Project } \\
\text { Closure }\end{array}$ & $\begin{array}{l}\text { MAN.3. BP15: } \\
\text { Perform project } \\
\text { close-out review }\end{array}$ \\
\hline $\begin{array}{l}\text { SI.1 SW } \\
\text { Implementation } \\
\text { Initiation }\end{array}$ & $\begin{array}{l}\text { 6.3.1.3.3 Project } \\
\text { Activation }\end{array}$ & $\begin{array}{l}\text { MAN.3. BPI1: } \\
\text { Implement the project } \\
\text { plan }\end{array}$ \\
\hline $\begin{array}{l}\text { SI.2 SW } \\
\text { Requirements } \\
\text { Analysis }\end{array}$ & $\begin{array}{l}\text { 6.4.1 Stakeholder } \\
\text { Requirements } \\
\text { Definition,7.1.2 SW } \\
\text { Requirements } \\
\text { Analysis }\end{array}$ & $\begin{array}{l}\text { ENG. } 1 \text { Requirements } \\
\text { elicitation, } \\
\text { ENG.4 Software } \\
\text { requirements analysis }\end{array}$ \\
\hline $\begin{array}{l}\text { SI.3 SW } \\
\text { Architectural and } \\
\text { Detailed Design }\end{array}$ & $\begin{array}{l}\text { 7.1.3 SW } \\
\text { Architectural Design } \\
\text { and 7.1.4 SW } \\
\text { Detailed Design }\end{array}$ & $\begin{array}{l}\text { ENG.5 Software } \\
\text { design }\end{array}$ \\
\hline $\begin{array}{l}\text { SI.4 SW } \\
\text { Construction }\end{array}$ & $\begin{array}{l}7.1 .5 \mathrm{SW} \\
\text { Construction }\end{array}$ & $\begin{array}{l}\text { ENG.6 Software } \\
\text { construction }\end{array}$ \\
\hline $\begin{array}{l}\text { SI.5 SW Integration } \\
\text { and Tests }\end{array}$ & $\begin{array}{l}\text { 7.1.6 SW } \\
\text { Integration and7.1.7 } \\
\text { SW Qualification } \\
\text { Testing }\end{array}$ & $\begin{array}{l}\text { ENG.7 Software } \\
\text { integration and } \\
\text { ENG.8 Software } \\
\text { testing }\end{array}$ \\
\hline $\begin{array}{l}\text { SI.6 Product } \\
\text { Delivery }\end{array}$ & $\begin{array}{l}6.4 .7 \mathrm{SW} \\
\text { Installation, } \\
6.4 .8 \mathrm{SW} \\
\text { Acceptance Support }\end{array}$ & $\begin{array}{l}\text { ENG.11 Software } \\
\text { installation, } \\
\text { SPL.3 Product } \\
\text { acceptance support }\end{array}$ \\
\hline
\end{tabular}

\section{1 .215504}

ISO 15504 [3] separates process and capability levels in two dimensions. In the process dimension, individual processes are described in terms of Process Title, Process Purpose, and Process Outcomes as defined in ISO/IEC 12207 (where each life cycle process is also divided into a set of activities; each activity is further divided into a set of tasks [4]). This decomposition is a Process Reference Model (PRM) aligned on the 12207 PRM. For instance, the 7.1.2 Software Requirements Analysis Process [4] defines 8 outcomes, 1 activity and 3 tasks. In addition, the 15504 process dimension provides: a) a set of Base Practices (BP) for the 
process providing a definition of the tasks and activities needed to accomplish the process purpose and fulfil the process outcomes; b) a number of input and output Work Products (WP) related to one or more of its outcomes; and c) characteristics associated with each work product [3]. As an example, ENG.4 Software requirements analysis Process defines 6 BPs, 4 input WPs and 6 output WPs [3]. The capability dimension consists of six capability levels (Level 0 reflects an incomplete process) and the process capability indicators for nine Process Attributes (PA) for levels 1 to 5. Figure 1 represents the two dimensions and a performance of process assessment.

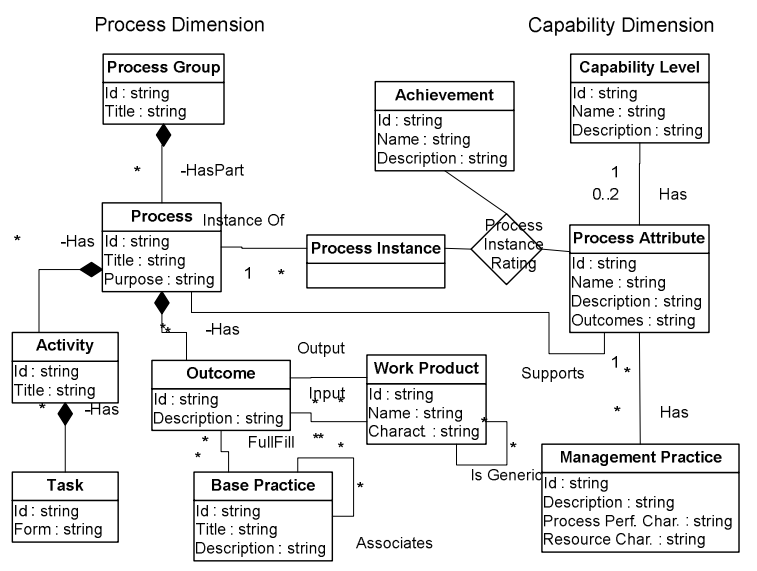

Figure 1. Reference Models. Performing a process assessment yields a rating for each process attribute. A rating is a judgment of the degree of achievement (None, Partially, Largely, Fully) of the process attribute for the instance of the assessed process.

\subsection{ISO/IEC 29110 Profile to 15504}

As specified in ISO/IEC DTR 29110-3, "a VSE specific Process Assessment Model (PAM) can be derived by selecting only the assessment indicators in the 15504-5 Exemplar PAM, relevant to the corresponding process outcomes defined in ISO/IEC 29110-41." In ISO/IEC DTR 29110-5-1-2, each objective is associated with a list of the processes for the basic profile from ISO/IEC 12207 and its outcomes related to the objective. For instance, the SI.02 objective profiled from the 7.1.2 Software Requirements Analysis Process outcomes (15504 ENG.4) is reduced to 4 selected outcomes. Applying the profiled objectives to the Base Practices of ENG.4, we can suppress Base Practices that do not contribute to the selected outcomes $(1,2,6$, and 8$)$.

Each PM objectives can be related in a quite simple manner to one, two or three processes of the 15504 (mostly in the MAN process group). Each SI objectives can also be related to one or two processes of the 15504 (mostly in the ENG process group). Hence, profiling 15504 Base Practices for the ISO/IEC 29110 PM and SI processes is straightforward. Grouping all profiled BP of concerned 15504 processes gives the reduction ratio of this profiling operation. Grouping is presented in Table 2.

\section{Capability dimension}

\subsection{4}

Clause 5 of ISO/IEC 15504-2 defines a measurement framework for the assessment of process capability defined on a six point ordinal scale: 0-Incomplete, 1-Performed, 2-Managed, 3Established, 4-Predictable, 5-Optimizing. The scale represents increasing capability of the implemented process, from Level 0 : not achieving the process purpose (or not implement the process) to meeting current and projected business goals [3]. Within this measurement framework, the measure of capability is based upon a set of process attributes (PA). Each attribute defines a particular aspect of process capability. Clause 6 of the 15504-5 presents the process capability indicators related to the process attributes associated with capability levels 1 to 5. Process capability indicators are the means of achieving the capabilities addressed by the considered process attributes. Most literature about Process Assessment for VSEs agrees that level 3 is the maximum that can be reached by a VSE.

Table 2. Reduced 15504 Processes and Base Practices

\begin{tabular}{|l|l|l|l|}
\hline $\begin{array}{l}\text { 15504 } \\
\text { related } \\
\text { process }\end{array}$ & Objective & \multicolumn{1}{|c|}{$\begin{array}{c}\text { Profiled 15504 } \\
\text { outcomes }\end{array}$} & $\begin{array}{c}\text { Profiled Base Practices (Total } \\
\text { number of BP) }\end{array}$ \\
\hline \multicolumn{3}{|c|}{ Supply Process Group (SUP) } \\
\hline SPL.3 & $\begin{array}{l}\text { PM.02 } \\
\text { SI.06 }\end{array}$ & 1) 2) & BP1, BP2 (4) \\
\hline \multicolumn{3}{|c|}{ Engineering Process Group (ENG) } \\
\hline ENG.2 & SI.02 & 1) & BP2 (6) \\
\hline ENG.4 & $\begin{array}{l}\text { SI.02 } \\
\text { PM.03 }\end{array}$ & 1) 2) 6) 7) 8) & BP1, BP3, BP5, BP6 (6) \\
\hline ENG.5 & SI.03 & All outcomes & All BPs : BP1 to BP5 (5) \\
\hline ENG.6 & $\begin{array}{l}\text { SI.03 } \\
\text { SI.04 }\end{array}$ & 1) 2) 3) 4) & All BPs : BP1 to BP4 (4) \\
\hline ENG.7 & SI.05 & 3) 4) 5) 6) & BP3, BP4, BP5, BP6 (6) \\
\hline ENG.8 & SI.05 & 1) 2) 3) & BP1, BP2, BP3 (4) \\
\hline \multicolumn{3}{|c|}{ Management Process Group (MAN) } \\
\hline MAN.3 & $\begin{array}{l}\text { PM.01 } \\
\text { SI.01 }\end{array}$ & 1) 3) 4) 5) 6) 7) & $\begin{array}{l}\text { BP1, BP2, BP4, BP5, BP6, } \\
\text { BP7, BP8, BP9, BP10, BP11, } \\
\text { BP12, BP13, BP14, BP15 (15) }\end{array}$ \\
\hline MAN.5 & PM.05 & 3) & BP3 (7) \\
\hline MAN.6 & $\begin{array}{l}\text { PM.01 } \\
\text { PM.02 }\end{array}$ & 2) 5) 6) & BP3, BP5, BP6, BP7, BP8 (9) \\
\hline \multicolumn{5}{|c|}{ Support Process Group } \\
\hline SUP.1 & PM.07 & All outcomes & All BPs : BP1 to BP5 (5) \\
\hline SUP.2 & SI.07 & All outcomes & All BPs : BP1 to BP5 (5) \\
\hline SUP.3 & SI.07 & 1) 2) 3) 4) 6) & BP1, BP2, BP3, BP4, BP6 (6) \\
\hline SUP.4 & PM.04 & 1) 3) 4) 5) & BP1, BP2, BP4, BP5, BP6 (6) \\
\hline SUP.7 & SI.06 & 1) 3) 5) & BP1, BP4, BP5, BP6, BP7 (8) \\
\hline SUP.8 & PM.06 & 1) 2) 3) 4) 6) & BP1, BP2, BP3, BP4, BP6 (6) \\
\hline SUP.9 & PM.02 & 2) 5) & BP2, BP3, BP9, BP10 (10) \\
\hline
\end{tabular}

\subsection{Application to a VSE}

We compiled the Process Attributes (PA) for level 1 and 2, generic practices per PA (an activity that, when consistently performed, contributes to the achievement of a specific process attribute [3]) and tried to figure out the implementation for each process (see examples in Table 3 ).

The continuous model of 15504 allows each process to be measured independently. But we are faced with different issues regarding PM and SI processes. PM is essentially a simplification of MAN.3 Project Management; hence generic practices are tailored once for the whole PM process. But SI is a collection of 6 low-level processes (from Initiation to Delivery) and each generic 
practice has to be declined in 6 exemplars. It seems us affordable for the PA 2.2 Work product management attribute, but much harder with the PA 2.1 Performance management attribute. Performance management is a huge issue and it does not seem possible to imagine that a VSE can afford the work required to adapt PA 2.1 Performance management attribute to its different processes. Table 3 shows some generic practices related to PA 2.2 and PA 2.1.

Table 3. Process Attributes for Levels 1 to 3

\begin{tabular}{|c|c|c|c|}
\hline \begin{tabular}{|l|} 
Process \\
Attribute
\end{tabular} & $\begin{array}{l}\text { Pro- } \\
\text { cess }\end{array}$ & Generic practices & Comment \\
\hline \multicolumn{4}{|c|}{ Level 2 "Managed" } \\
\hline $\begin{array}{l}\text { PA 2.1 } \\
\text { Perfor- } \\
\text { mance } \\
\text { mana- } \\
\text { gement } \\
\text { attribute }\end{array}$ & $\begin{array}{c}\text { PM } \\
\text { SI }\end{array}$ & $\begin{array}{l}\text { GP 2.1.1 Identify the objectives for the } \\
\text { performance of the process } \\
\text { 1. Identify the objectives for the } \\
\text { performance of the process. } \\
\text { 2. The scope of the process performance } \\
\text { is defined. } \\
\text { 3. Assumptions and constraints are } \\
\text { considered when identifying the } \\
\text { performance objectives. }\end{array}$ & $\begin{array}{l}\text { It may be } \\
\text { considered for } \\
\text { PM, but out of } \\
\text { reach for all } \\
\text { sub-processes } \\
\text { of SI. }\end{array}$ \\
\hline \multicolumn{4}{|c|}{$\ldots$} \\
\hline $\begin{array}{l}\text { PA } 2.2 \\
\text { Work } \\
\text { product } \\
\text { mana- } \\
\text { gement } \\
\text { attribute }\end{array}$ & $\begin{array}{c}\text { PM } \\
\text { SI }\end{array}$ & $\begin{array}{l}\text { GP 2.2.2 Define the requirements for } \\
\text { documentation and control of the work } \\
\text { products } \\
\text { 1. Requirements for the documentation } \\
\text { and control of the work products are } \\
\text { defined } \\
\text { 2. Dependencies between work products } \\
\text { are identified and understood } \\
\text { 3. Requirements for the approval of work } \\
\text { products to be controlled are defined }\end{array}$ & $\begin{array}{l}\text { 1. } 2 \text {. and } 3 \text {. } \\
\text { shall be } \\
\text { defined once, } \\
\text { but are } \\
\text { submitted to } \\
\text { change. }\end{array}$ \\
\hline
\end{tabular}

\subsection{Merging the two dimensions}

Although the MARES approach refers to the 15504, they do not use the 2-dimension model of the 15504 and concentrates on the process dimension. The RAPID approach [9] defines a complete set of 210 questions / indicators for each process across capability levels 1, 2 and 3. However most approaches such in [9], [10] are relating the use of the CMMI rather than the 15504 standard.

Both models have different architecture and focus. 15504 separates processes and capability levels in two dimensions while CMMI handles them in one dimension. CMM focuses on an organization's capability whereas the 15504 standard focuses on a single process capability. The latter seems more suitable to a VSE because improvement can be conducted process per process, rather than a global step as the staged CMMI.

However, it should be pointed out that separate process and capability dimensions may discourage a VSE regarding process assessment. Concerning capability level 1 , Process Attribute (PA) indicators relate to the process dimension regarding the extent of the process purpose and outcome achievement. As these issues form a part of process definition in the ISO/IEC 29110 standard, a VSE implementing correctly the Basic Profile for instance, will achieve fully or largely Level 1 PAs. Capability Level 2 indicators relate to define, plan, monitor and adjust performance of each process and to identify, define, document, review and adjust each work products. We make the proposal to incorporate Level 2 PAs inside Intermediate or Advanced Profile Processes definitions. PA 2.1 will require highlighting how to identify resource requirements, how to plan the performance of the process, how to implement the defined activities and how to manage the execution of the activities of each Profile Processes. PA 2.2 will require highlighting how to identify work products requirements, how to identify the activities associated with work products, how to manage the configuration of work products, and how to manage the quality of work products.

The challenge of this two-dimensional merging is to preserve usefulness of Process Attributes while keeping processes definition as simple as possible. However a big step will be accomplished by a VSE if PM, SI and its 6 sub-processes are implemented along this unified view because the VSE will probably reach a capability level 2 .

\section{CONCLUSION}

Two main ideas are presented in this paper (1) we established a set of Base Practices conforming to the ISO/IEC 29110 Basic Profile and reduced from ISO 15504-5 "An exemplar Process Assessment Model"; (2) we set the question of the suitability of the 15504 bi-dimensional model for Process Assessment in a VSE and we propose to develop a unified view of processes incorporating Level 2 PAs. A VSE implementing Base Practices of Basic Profile may be delighted to learn - as Monsieur Jourdain in Moliere's comedy The Middle-Class Gentleman - that the VSE has been "speaking" a capability level 1 without knowing it. Our objective is to contribute to the Intermediary Profile in order to let VSEs "speaking" a capability level 2 without knowing it.

\section{REFERENCES}

[1] ISO/IEC 29110:2010. Software Engineering - Lifecycle Profiles for Very Small Entities (VSE). ISO, Geneva.

[2] Laporte, C.Y., Alexandre, S., and O'Connor, R.V. 2008. A Software Engineering Lifecycle Standard for Very Small Enterprises. In Proceedings of the $15^{\text {th }}$ EuroSPI Conference. CCIS Vol. 16, Springer-Verlag, Berlin Heidelberg. (September 1-5, 2008), 129-141.

[3] ISO/IEC 15504:2004. Information technology -- Process assessment. ISO, Geneva: ISO.

[4] ISO/IEC 12207:2008. Information technology -- Software life cycle processes. ISO, Geneva: ISO.

[5] ISO/IEC 15289:2006. Systems and software engineering -Content of systems and software life cycle process information products. ISO, Geneva.

[6] von Wangenheim, C. G., Anacleto, A., and Salviano, C. F. 2006. Helping Small Companies Assess Software Processes. IEEE Software 23, 1 (Jan. 2006), 91-98.

[7] Cater-Steel, A. P. 2001. Process Improvement in Four Small Software Companies. In Proceedings of the 13th Australian Conference on Software Engineering (August 27 - 28, 2001). IEEE Computer Society, Washington, DC, 262.

[8] Rout, T. P., Tuffley, A., Cahill, B., and Hodgen B. 2000. The Rapid Assessment of Software Process Capability. In Proceedings of SPICE 2000. 47-55.

[9] Grunbacher, P. 1997. A software assessment process for small software enterprises. In Proceedings of the 23rd EUROMICRO Conference (September 1-4, 1997), 123-128.

[10] Mc Caffery, F., Taylor, P.S., and Coleman, G. 2007. Adept: A Unified Assessment Method for Small Software Companies. IEEE Software 24, 1 (Jan-Feb 2007), 24-31. 
